Марија Н. Вујовић

Школа страних језика „Логос”

Београд
УДК 81'243’23

https://doi.org/10.18485/uzdanica.2020.17.2.11

Прегледни рад

Примљен: 31. август 2020.

Прихваћен: 23. новембар 2020.

\title{
ЈЕЗИЧКИ ФАКТОРИ КОЈИ УТИЧУ НА ТРАНСФЕР
}

$A \bar{u} c \bar{u} р а \kappa \bar{u}:$ Међујезички утицај или трансфер, који се нужно појављује током учења страног језика, већ дуго је у фокусу интересовања лингвиста које занима на који начин претходно језичко знање утиче на процес учења новог језика. Истраживања у овој области узимају у обзир и факторе који утичу на трансфер. Ти фактори могу бити језички и нејезички. Циљ овог рада је да сублимира знања о језичким факторима који утичу на трансфер из перспективе психолингвистике и истакне најрелевантнија емпиријска истраживања обављена у овом пољу.

Кључне речи: трансфер, међујезички утицај, фактори, језичка типологија, психотипологија, ефекат страног језика.

Трансфер, или данас радије коришћен термин међујезички уйицај (енгл. cross-linguistic influence), дефинише се као утицај знања једног језика на знање или употребу другог језика (Џарвис, Павленко 2008). Реч је о језичком феномену који се састоји у стратешком коришћењу доступних језичких ресурса матерњег (или неког другог познатог језика) како би се компензовали недостаци или ограничена знања о циљном језику (Де Диос Мартинес Агудо 2004). Најједноставније речено, трансфер је примена правила матерњег или неког другог, већ наученог језика у покушају стварања продукције на новом језику, која у неким случајевима доводи до одступања од норми циљног језика, а у другим случајевима олакшава учење.

О врстама трансфера (позитивни и негативни, трансфер позајмљивања и суптрактивни трансфер, фонетски, лексичко-семантички, морфолошко-синтаксички, прагматички, концептуални итд.) писало се често у научној литератури. Међутим, детаљно приказани фактори који утичу на трансфер нису били честа тема научних радова. Стога је наш циљ био да, на једном месту, дамо преглед најзначајнијих језичких варијабли које утичу на трансфер и издвојимо најрелевантнија истраживања у овој области.

Студије о међујезичком утицају откриле су бројне факторе који утичу на учење циљног језика и који могу да предвиде који ће од претходно 
научених језика бити језик из кога потиче трансфер. Они се могу поделити на две велике групе (језички и нејезички) и у великој мери зависе једни од других (Келерман 1983; Вилијамс, Хамарберг 1998; Сенос 2001; Де Анђелис, Селинкер 2001; Рингбом 2001).

У групу језичких фактора који утичу на трансфер у процесу учења циљног језика спадају: језичка типологија, психотипологија, ефекат страног језика, ниво знања језика, скорашњост коришћења, изложеност циљном језику и редослед учења језика.

Језичка типологија (типолошка сличност, језичка дистанца, или енгл. language distance) важи за један од кључних фактора у одређивању опсега међујезичког утицаја у учењу и употреби циљног језика (Ахукана и др. 1981; Рингбом 1986; Вилијамс, Хамарберг 1998; Дуел 1998). Под овим термином подразумева се објективна типолошка удаљеност између два или више језика, тј. степен структурних, лексичких и других сличности или разлика који могу да идентификују лингвисти на основу стручног знања из области лингвистике (Де Анђелис 2007: 22).

Међутим, када се говори о језичкој типологији као фактору који утиче на трансфер, поједини лингвисти (Фолк, Бардел 2010) истичу да је неопходно направити разлику између језичке повезаности (енгл. language relatedness) и језичке типологије. Према њиховом мишљењу, повезаност језика односи се на општију класификацију језика у смислу њиховог порекла или језичке породице којој припадају, док се типологија односи на разлике и сличности одређених језичких структура између језика који нису генетски повезани. Упркос њиховом ставу, у литератури преовладава дефиниција која под језичком типологијом подразумева проучавање сличности или заједничких карактеристика које деле језици и класификује их у складу са њиховим структурним карактеристикама (фонетским, фонолошким, лексичким, морфолошким, синтаксичким, дискурсним).

Значајем фактора језичке типологије бавиле су се разне емпиријске студије (Вилијамс, Хамарберг 1998; Дуел 1998; Сенос 2001; Де Анђелис, Селинкер 2001) у настојању да објасне зашто у неким случајевима у процесу учења L $3^{1}$, L4 итд. ученици напусте свој матерњи (најпознатији) језик као извор за трансфер и прибегну другом језику и усагласиле се у томе да у проучавању трансфера не треба обратити пажњу искључиво на утицај матерњег језика на циљни, већ и на утицај L2 на циљни језик, посебно у случају када je L2 типолошки најближи циљном језику.

Некада је Кордер (1983: 21) тврдио да сличности између језика могу олакшати процес учења циљног језика, док разлике између два језика отежавају овај процес. Вајнрајх је истицао да је концепт језичке удаљености

${ }^{1} \mathrm{~L} 1$ - матерњи језик, L2 - први страни језик, L3 - други страни језик, L4 - трећи страни језик. 
између матерњег језика и L2 пресудан: што су језици удаљенији, односно што је већа разлика између два система, веће су и потешкоће и, супротно томе, што су језици блискији, мање су потешкоће (Вајнрајх 1953: 1). На тим претпоставкама се заснивала контрастивна анализа и истраживања о учењу другог језика неколико последњих деценија прошлог века. Емпиријска истраживања која су уследила доказала су супротно: уколико су језици из исте језичке породице, у појединим фазама учења негативни трансфер ће се чешће јављати него у случајевима када језици нису слични, тј. управо међујезичке сличности могу да отежавају учење циљног језика.

Испитивање важности овог фактора посебно је интересантно код учењa L3. У тројезичним контекстима поставља се питање који језик ће бити доминантнији ресурс за трансфер и које језичке јединице ће се чешће преносити из језика у језик. У том смислу испитиване су различите комбинације језика: игбо, енглески и француски (Ахукана и др. 1981), фински, шведски и енглески (Рингбом 1986), енглески, шпански и француски (Синглтон 1987).

Досадашња истраживања утицаја језичке типологије на учење L3 показују да језик који је типолошки најближи циљном језику обично има највећи утицај (Ахукана и др. 1981; Вилијамс, Хамарберг 1998; Дуел 1998; Сенос 2001; Де Анђелис, Селинкер 2001).

Ахукана и др. (1981) открили су да је утицај енглеског (L2) на учење француског језика (L3) био већи од утицаја језика игбо, који је био L1 камерунских ученика. Сенос (2001) је спровела истраживање у коме је, како би испитала фактор језичке типологије, поредила продукције ученика чији је L1 типолошки близак, a L2 типолошки удаљен од њиховог L3 са продукцијама ученика чији је L1 типолошки удаљен, a L2 типолошки близак њиховом L3. Прву групу чинили су испитаници који говоре баскијски као L1 и шпански као L2, другу групу испитаници који говоре шпански као L1 и баскијски као L2, a трећу групу чинили су двојезични говорници баскијског и шпанског. Шпански језик је био извор трансфера у енглески језик за све три групе због типолошке блискости између ова два језика, бар када је лексика у питању, јер шпански и енглески, за разлику од баскијског, припадају истој породици индоевропских језика. Рингбом (1986) сматра да је језичка типологија доминантнија у односу на друге факторе као што су учесталост употребе и степен изложености језику. Анализирао је продукције матерњих говорника финског и матерњих говорника шведског који живе у Финској. Истраживање је показало да на изворне говорнике шведског није утицао њихов L2 (фински) у току учења енглеског као L3, упркос чињеници да су живели у средини где су свакодневно били изложени финском. С друге стране, изворни говорници финског обилно су користили свој L2 (шведски) у продукцији на L3 (енглески), иако нису често изложени шведском. Дакле, ученици у обе групе су били више под утицајем шведског него финског, пошто су енглески и шведски германски језици, док фински није. 
Психотипологија (енгл. psychotypology, typological proximity, perceived typological similarity) је термин који је сковао Келерман (Де Анђелис 2007: 22) и дефинисао га као ученикову перцепцију релативне сличности између два језика, која може или не мора да се поклапа са стварним типолошким везама које постоје између структура тих језика. Удаљеност између два језика може се одредити са лингвистичког аспекта (стварна блискост или удаљеност између језика) или психолошког (говорник може имати одређену, свесну или несвесну, перцепцију те удаљености). Психотипологија је начин на који ученик доживљава језичку удаљеност између језика који већ познаје и циљног језика, односно степен подударања за који говорник сматра да постоји између та два језика.

За појаву трансфера перципирана блискост између два језика може бити значајнија од њихове реалне, типолошки доказане сличности (Одлин 1989). Ако се два језика перципирају као сродна у односу на одређену структуру, вероватније ће доћи до трансфера, док ће перцепција различитости имати тенденцију да доведе до избегавања одређене циљне структуре. Сличности између језичких система су главни узрок за активацију два или више језика. Келерман (1983: 113) је тврдио да „није преносиво све што изгледа преносиво" и да морају постојати нека ограничења која спречавају трансфер из L1 у L2 између одређених конгруентних структура. Ученикова перцепција језичке дистанце је кључни фактор у одређивању преносивости елемената између језика. Трансфер се не заснива на реалној конгруентности елемената L1 и L2, већ на процени коју ученик има о свом L1 пре него што сазна нешто о одговарајућој структури у L2. Другим речима, ученик који учи нови језик правиће хипотезе о том језику. Ученикова перцепција језичке дистанце ће одређивати преносивост елемената између језика. Уколико ученик верује да су полазни језик и циљни језик у неком смислу исти, доћи ће до трансфера. Истовремено, трансфер ће бити заустављен ако изостане учеников субјективни суд о међујезичкој блискости.

Исто важи и за вишејезичне говорнике. Ученици који примећују везе између L2 и L3 лакше ће научити L3 од оних који те сличности не виде. Ако ученик свој L1 не доживљава као близак са циљним језиком, a L2 перципира као повезан са циљним језиком, више ће се ослањати на знање L2 него на свој матерњи језик. Ученикова субјективно донесена процена о типолошким односима између језика није увек иста, већ ће се мењати како ученици буду добијали више информација о циљном језику. Што је ученикова компетенција на циљном језику нижа, то се он више служи својим претходним језичким знањем, тако да је трансфер најјачи на ниском нивоу компетенције циљног језика (Келерман 1983). То није случај са објективним сличностима које су константне. Дакле, вероватније је да ће доћи до трансфера, и позитивног и негативног, уколико ученик процени језике као сличне или повезане. 
Де Анђелис и Селинкер (2001: 51) у свом истраживању закључују да ако ученик доживљава да је одређени L2 типолошки ближи циљном језику, он ће преносити форме из овог језика на циљни језик како би надокнадио недостатак компетенције на циљном језику. Рингбом (2001) тврди да је значај овог фактора на међујезички трансфер најочигледнији на пољу лексике и да ће говорници са ниским нивоом знања L3 често користити облике из L2, ако они сами закључе да L2 и L3 повезује низ заједничких чинилаца.

Ефекат страног језика (енгл. foreign language effect) је први приметио Мајзел 1983. године, док се исти феномен, под другачијим називом (status L2) налази и код Хамарберга 2001. године (Сенос 2001: 9). Реч је о тенденцији ученика L3 да користе радије свој L2 као извор транфера уместо L1. Наиме, ученици настоје да потисну L1 („нестрани” језик) и да активирају cвоj L2 (страни језик) приликом учења L3, jep L2 има исти статус страног језика као и L3 и механизам учења L2 је много сличнији оном који је потребан за учење L3 него механизам који се активира приликом усвајања L1.

Бројне студије су испитивале значај овог фактора на језички трансфер. Испоставило се да информанткиња, у истраживању које су обавили Вилијамс и Хамарберг (1998: 323), чешће прави трансфер из нематерњег језика јер верује да употреба језика који није матерњи представља бољу стратегију за учење другог страног језика. У истраживању се дошло до закључка да је L1 (енглески језик) коришћен свесно и намерно (јер је информанткиња знала да саговорник добро познаје овај језик), док је L2 (немачки) употребљаван несвесно или подсвесно у конструкцијама које (вероватно због ниског нивоа знања) не би биле активиране у циљном језику (шведском). Хамарберг у свом раду из 2001. за информанта има ученика са енглеским као матерњим језиком, немачким као L2, француским и италијанским језицима као претходно ученим страним језицима и шведским језиком који тренутно учи као L3. Аутор закључује да, иако су матерњи језик (енглески) и L2 (немачки) типолошки блиски циљном језику, шведском, ученик има тенденцију да користи немачки језик као извор трансфера како би надоместио недостатак знања шведског језика, што потврђује утицај фактора статуса L2. Хамарберг наводи два могућа разлога за појаву овог фактора (Исто: 36-37): 1) постоји другачији механизам за учење L2 у поређењу ca L1 и стога се овај механизам реактивира у процесу учења L 3,2 ) ученици имају жељу да „искључе” L1 као „нестрани језик” како би продукција на циљном језику била више „страна” и стога постоји тенденција да се ослањају на L2, као стратегија приближавања циљном језику, L3.

Де Анђелис и Селинкер (2001: 56) сматрају да ученици трећег језика прибегавају трансферу из другог језика јер не желе да им трећи језик личи на први (матерњи), већ желе да он звучи као страни језик. Ипак, у највећем броју случајева трансфер у циљни језик се дешава из типолошки сличнијег језика, тако да фактор језичке удаљености и статус другог језика не би требало 
посматрати одвојено, већ кроз њихово међусобно узајамно дејство. Бардел и Фолк (2007) тврде да је фактор статуса L2 евидентан и у учењу синтаксе L3, пошто су откриле да је L2 био извор трансфера у синтакси L3, независно од типолошке сличности или генетске повезаности језика. На лексичком нивоу, постоји студија Филиатове (2010) која је истраживала фактор статуса L2, са 14 информаната, матерњих говорника руског језика чији је L2 био енглески, a L3 шпански. Студија је показала да су ученици фаворизовали L2 у односу на L1, чак и у случајевима када је сличност између L1 и L3 била већа него између L2 и L3 (Филиатова 2010: 2).

Ниво знања језика (енгл. proficiency) односи се на степен знања претходно наученог/их језика, али и циљног језика. Иако према већини студија важи за значајан фактор који утиче на трансфер, емпиријски докази још увек нису дали јасну слику о томе какав утицај ниво знања има на међујезички утицај.

Када је у питању трансфер у процесу учења L2, већина лингвиста се слаже у тврдњи да је код ученика са нижим нивоом знања циљног језика јачи трансфер из матерњег језика него код оних који имају виши ниво знања циљног језика (Рингбом 1987; Вилијамс, Хамарберг 1998; Сенос 2001). У овој фази најчешће се ради о негативном трансферу, управо због ниског нивоа знања циљног језика и још увек доминантног матерњег језика ученика, док се позитивни трансфер очекује на вишим нивоима, када компетенција коју имају ученицима дозвољава да повезују структуре два језика и тиме олакшају себи процес учења (Одлин 1989).

Када је реч о учењу L3, с обзиром на сложену језичку конфигурацију вишејезичног говорника, ситуација је компликованија јер је неопходно размотрити језичку компетенцију, не само на циљном језику већ и на два друга језика која ученик познаје.

Већина лингвиста који су се бавили овим феноменом тврди да је вероватноћа да дође до трансфера већа у почетној фази учења, када постоји јаз између недовољног знања ученика и потребе да попуни празнине у знању L3, као и да се међујезички утицај смањује како знање циљног језика расте (Вилијамс, Хамарберг 1998).

Такође, веруjе се да ниво знања L2 утиче на степен до ког ћe L2 бити присутан током продукције L3, тј. да ученик мора да поседује извесни ниво знања L2 да би он утицао на L3 (Трамбле 2006). Тешко је да ће извор трансфера бити низак ниво знања језика, извесније је да ће то бити висок ниво знања језика (Одлин 1989; Рингбом 2001; Хамарберг 2001). Ако ученик поседује низак ниво знања одређеног језика, мало је вероватно да ће користити своје знање овог језика као ресурс за учење другог језика.

Навешћемо само нека од истраживања релевантних за фактор нивоа знања језика. У већ поменутој студији (Вилијамс, Хамарберг 1998) аутори су, поред других фактора, анализирали и нивоа знања језика. Открили су да 
када студент L3 има високу компетенцију у L1 и L2, оба језика играју важну улогу у процесу учења L3, али на другачији начин: док је L1 имао инструменталну улогу (информанткиња/коауторка студије га је користила за решавање проблема везаних за израду задатка, тражење појашњења, разјашњење недоумица), L2 је био језик „снабдевач” (supplier) и утицао је директно на учење L3. Tрамбле (2006) анализира продукцију на немачком (L3) групе говорника енглеског (L1) и француског језика (L2), где говорници имају различите нивое знања L2 и степен изложености другом језику. Резултати показују да je утицај L2 (француског) на учење вокабулара трећега језика највећи код студената који су имали већи ниво знања и изложености другом језику, али да је ипак главни извор трансфера био први језик (енглески). Дакле, највећи утицај на L3 долазио је из L1, с напоменом да се тај утицај смањивао како се компетенција у L3 повећавала.

Различите студије које су истраживале фактор нивоа знања језика, самостално или у интеракцији са другим факторима, дошле су до резултата који су често потпуно опречни. Такви супротстављени резултати могу се објаснити чињеницом да су у овим истраживањима коришћени различити инструменти за прикупљање података (интервјуи, упитници, састави, преводи итд.). Џарвис и Павленко (2008) као могуће разлоге наводе и то да истраживачи мере ниво знања језика на различите начине, тј. да као параметре узимају дужину боравка у земљи чији се језик учи као циљни језик, дужину времена учења језика итд. Поред тога, треба узети у обзир и да ли се фактор нивоа знања језика испитује кроз учење, тј.рецепцију, или продукцију ученика.

Скорашњост коришћења (утицај „најскоријег”, ефекат последњег језика, енгл. recency of use, last language effect) је фактор који се односи на претпоставку да је већа вероватноћа да ће ученици као језички ресурс употребљавати језик који тренутно користе, него други језик који су раније учили, али не користе.

Де Анђелис (2007: 35) дефинише овај фактор као „колико скоро је језик последњи пут коришћен”. Хамарберг (2001: 23) тврди да се „L2 активира лакше ако га је ученик користио недавно и на тај начин задржао лакши приступ до њега". Дакле, постоји велика могућност да у нематерњој продукцији ученика трансфер може да потекне од нематерњег језика коме је тренутно највише изложен.

Вилијамс и Хамарберг (1998) испитују четири фактора који могу утицати на трансфер: ниво знања језика, језичку типологију, скорашњост коришћења и статус L1/L2. Информанткиња, истовремено и коауторка студије, као матерњи говорила је енглески, њен L2 je био немачки, а као L3 учила је шведски језик. Добијени резултати показали су да је највећи трансфер потицао из немачког, што доказује утицај фактора скорашњости коришћења, бар у почетној фази учења L3. Дуел (1998) у свом истраживању анализира лексеме у говорној продукцији информаната које су морфолошки и фонолошки 
прилагођене циљном језику, али које никад не користе изворни говорници, а које аутор назива „лексички изуми” (енгл. lexical inventions). Упоређујући продукцију холандских ученика, оних којима је француски L2 и оних којима је француски L3, закључује да француски има виши ниво активације код говорника којима је овај језик L2 него код говорника којима је тај језик L3. Активни језик са највишим нивоом активације је већи извор лексичких информација, док је приступ лемама језика који имају нижи ниво активације делимично блокиран. Редослед учења језика и њихова активација условљава трансфер у циљном језику, што значи да L1 није увек доминантан активни језик. Еке (2001) спроводи истраживање које се тиче учења и обраде речи у L3, њихове организација и односа према другим речима у менталном лексикону ученика с циљем да испита количину, изворе и услове за међујезички утицај у лексичкој продукцији у L3, кроз задатак превођења речи. Аутор примећује слаб утицај матерњег језика на лексичку продукцију у L3, који се не може објаснити непостојањем сличности између матерњег језика и L3 јер су информанти прибегавали L2 чак и у случајевима када је постојала сличност између L1 и L3. Еке долази до закључка да је фактор последње коришћеног језика условио трансфер, иако у интеракцији са осталим факторима (психотипологија, статус L2).

Изложеност циљном језику (енгл. amount of exposure, exposure to the target language) је фактор који се односи на укупно време боравка ученика у земљи чији језик уче као циљни или на време учења циљног језика у формалном контексту (школском амбијенту), у земљи у којој циљни језик није матерњи језик становништва. Што се тиче мерења времена изложености циљном језику, може се мерити узимајући у обзир различите параметре: године учења језика, учесталост и интензитет изложености (број сати ученикове изложености језику на дневном или недељном нивоу) итд. (Џарвис, Павленко 2008). Степен изложености циљном језику има јак утицај на могућност појаве и позитивног и негативног трансфера (Одлин 1989).

Фаусер (2001) је спровео истраживање са два испитаника, ученика чији je L1 био енглески, који су учили корејски као трећи, односно пети језик и који су дуго времена живели у Јапану пре него што су почели да уче корејски језик. Оба ученика учила су јапански као нематерњи језик и оба су говорила течније јапански него корејски. Код једног ученика примећено је да често ненамерно користи корејски док говори јапански, а други је изјавио да често размишља на јапанском док говори корејски (Де Анђелис 2007: 37). Марфи (2003: 8) верује да фактор изложености језицима функционише слично код учења L2 и L3 и да повећана изложеност и употреба L3 доводи до мањег трансфера језика, иако поређење говорника L2 и L3 показује да је ова појава израженија код говорника L2 него код говорника L3. Разлог је вероватно тај што вишејезични говорници располажу обимнијим језичким системом који подразумева и више когнитивних ресурса којима треба управљати. У 
већ поменутом истраживању, осим фактором нивоа знања језика, Трамбле (2006) се бави и фактором изложености циљном језику. Резултати показују да у случајевима када ниво знања језика L2 утиче на учесталост употребе L2 током комуникације на L3, изложеност L2 ће утицати на ученикову способност да користи знање L2 како би превазишао лексичке потешкоће у L3.

У истраживањима се дошло до разних резултата у вези са фактором изложености циљном језику: доказано је да ученици L3 могу течније говорити циљни језик када живе у земљи где се L3 говори, док ученици L3 који језик уче у школском амбијенту у својој земљи тачније користе граматичка правила, да постоји веза између језичке компетенције и времена боравка у земљи циљног језика, али да постоји граница након које ученици не могу повећати ниво изложености језику.

Редослед учења језика (енгл. order of acquisition) је фактор коме је најмање пажње посвећено у литератури о трансферу. Разлог за то би могла бити чињеница да се овај фактор више везује за плурилингвалне него за билингвалне говорнике, а вишејезичност је постала предмет интересовања лингвиста тек у последње три деценије.

Када је у питању учење L2, постоје само две могућности: L1 и L2 су учени или узастопно или истовремено. Када је у питању учење L3, постоје четири могућа редоследа учења: 1) три језика су учена један за другим, 2) L2 и L3 су учени истовремено након L 1, 3) L1 и L2 су учени истовремено пре L3, 4) ученик је у истовременом додиру са три језика (Сенос 2000).

Једно од најзначајнијих истраживања у овој области је оно које смо већ поменули у делу рада који говори о фактору скорашњости коришћења. Дуел (1998) се бави „лексичким изумима” 39 говорника чији је матерњи језик холандски. Међу њима, 32 ученика знало је француски језик као L2, a енглески као L3, док је код 7 ученика француски био L3 и енглески L2. Корпус од 218 лексичких изума аутор је класификовао у две категорије: унутарјезичке и међујезичке. Прве су настале као резултат примене стратегија као што су прекомерна генерализација и поједностављивање, а друге као резултат активирања лема које нису припадале циљном језику. Ученици којима je L2 био француски су се више ослањали на L1, холандски, а ученици којима je L3 био француски су се више ослањали на L2, енглески. Дуел (1998: 488) закључује да је језик с високим нивоом активације онај који ће бити већи извор лексичке информације, док ће приступ лемама језика који има нижи ниво активације бити делимично блокиран. С обзиром на то да су обе групе информаната имале исту комбинацију језика (холандски, француски, енглески), аутор такође закључује да редослед учења језика и њихова активација могу одредити врсту и количину међујезичког утицаја у циљном језику, јер су резултати истраживања показали да су се ученици ослањали на претходно научени језик. 
Услед глобалног ширења енглеског језика, пораста вишејезичних говорника у свету због миграција становништва и превасходно залагања Брисела и Европске комисије да млади, поред матерњег, познају најмање још два језика, како би пронашли боља радна места на тржишту рада, плурилингвизам је постао више правило него изузетак. Самим тим и фокус лингвиста померен је на проблеме које се тичу учења више од једног страног језика. Стога не чуди што међујезички утицај и фактори који на њега утичу, посебно у контексту вишејезичности, представљају једну од најактуелнијих лингвистичких тема данас у Европи и свету. Ипак, у Србији, према нашим сазнањима добијеним на основу анализиране литературе, трансфер није добио заслужену пажњу у српској академској заједници и број домаћих студија на ову тему није велики. Последњих година појавило се неколико докторских дисертација на тему трансфера у нашој земљи. Д. Радовић у дисертацији „Међујезички утицаји у процесу усвајања трећег језика”, одбрањеној 2014. године у Новом Саду, говори о факторима који утичу на усвајање трећег језика. Три године касније, на ФИЛУМ-у у Крагујевцу одорањена је дисертација „Перцепција и продукција консонантског система у енглеско-српској међујезичкој фонологији", у којој се ауторка Д. Јеротијевић Тишма кратко осврнула на лингвистичке и ванлингвистичке факторе у оквиру међујезичке фонологије. Детаљније је о факторима који утичу на трансфер писала 2018. године С. Детар Јевђовић у дисертацији „Утицај енглеског језика на писану продукцију на италијанском код србофоних ученика", где је посебно обрадила факторе: ниво знања језика, количина изложености и употреба - учесталост коришћења језика и контекст учења језика. Исте године, ауторка $\mathrm{H}$. Момчиловић, у докторату „Немачки као други страни језик у Србији” пише о лингвистичким и другим интерним и екстерним факторима који могу да утичу на избор језика који је извор утицаја. Можда је најдетаљнији преглед језичких и нејезичких фактора који утичу на појаву трансфера дат у докторској дисертацији ауторке овог рада „Проблеми у процесу учења изазвани негативним трансфером у писаној продукцији српских студената који уче два типолошки сродна језика - случај италијанског као L2 и шпанског као L3" из 2019. године, одбрањене на Филолошком факултет у Београду.

Мишљења смо да истраживач који жели да на адекватан начин испита неки од језичких фактора нема лак задатак јер, поред наведених, на трансфер утичу и нејезички фактори (мотивација, став, надареност, интелигенциja, узраст, пол, формалност контекста, метајезичка свест итд.), а досадашња истраживања показала су да су ови фактори испреплетани и да у процесу трансфера суделује више њих. Поред тога, истраживач врло често нема на располагању довољно информација, а одговарајућа метода и информанти нису увек доступни. Треба напоменути да извор трансфера такође може да варира у зависности од језика који се тестира, методологије истраживања, језичког окружења информаната, области језичке анализе и других фактора. 


\section{ЛИТЕРАТУРА}

Ахукана, Лунд, Ђентиле (1981): Joshua Ahukanna, Nancy Lund, Ronald Gentile, Inter- and intra-lingual effects in learning a third language, Modern Language Journal, 65, USA: Wiley-Blackwell, 281-287.

Бардел, Фолк (2007): Camilla Bardel, Ylva Falk, The role of the second language in third language acquisition: The case of Germanic syntax, Second Language Research, 23, USA: SAGE Publications, 459-484.

Bajнрајх (1953): Uriel Weinreich, Languages in contact, findings and problems, New York: Linguistic Circle of New York.

Вилијамс, Хамарберг (1998): Sarah Williams, Björn Hammarberg, Language switches in L3 production: Implications for a polyglot speaking model, Applied Linguistics, 19, UK: Oxford University Press, 295-333.

Вујовић (2019): Marija Vujović, Problemi u procesu učenja izazvani negativnim transferom u pisanoj produkciji srpskih studenata koji uče dva tipološki srodna jezika - slučaj italijanskog kao L2 i španskog kao L3, doktorska disertacija, Beograd: Univerzitet u Beogradu - Filološki fakultet.

Де Анђелис (2007): Gessica De Angelis, Third or Additional Language Acquisition, Clevedon: Multilingual Matters.

Де Анђелис, Селинкер (2001): Gessica De Angelis, Larry Selinker, Interlanguage transfer and competing linguistic systems in the multilingual mind, In: J. Cenoz, B. Hufeisen, U. Jessner (Eds.), Cross-linguistic Influence in a Third Language Acquisition: Psycholinguistic Perspectives, Clevedon, UK: Multilingual Matters, 42-58.

Де Диос Мартинес Агудо (2004): Juan De Dios Martínez Agudo, Transferencia lingüística en el aprendizaje de una lengua extranjera, Granada: Editorial Geu.

Детар Јевђовић (2018): Snežana Detar Jevđović, Uticaj engleskog jezika na pisanu produkciju na italijanskom kod srbofonih učenika, doktorska disertacija, Beograd: Univerzitet u Beogradu - Filološki fakultet.

Дуел (1998): Jean-Marc Dewaele, Lexical inventions: French interlanguage as L2 versus L3, Applied Linguistics, 19, UK: Oxford University Press, 471-490.

Еке (2001): Peter Ecke, Lexical retrieval in a third language: evidence from errors and tip-of-the-tongue states, In: J. Cenoz, B. Hufeisen, U. Jessner (Eds.), Cross-linguistic Influence in Third Language Acquisition: Psycholinguistic Perspectives, Clevedon: Multilingual Matters, 90-114.

Јеротијевић Тишма (2017): Даница Јеротијевић Тишма, Перцейција и йроgук-

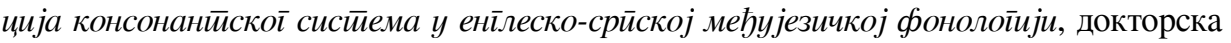
дисертација, Крагујевац: Универзитет у Крагујевцу - Филолошко-уметнички факултет.

Келерман (1983): Erik Kellerman, Now you see it, now you don't, In: S. Gass, L. Seliner (Eds.), Language Transfer in Language Learning, Rowley, MA: Newbury House, $12-34$.

Кордер (1983): Stephen Pit Corder, A role for mother tongue, In: S. M. Gass, L. Selinker (Eds.), Language transfer in language leamrning, Rowley, MA: Newbury House, 85-97. 
Момчиловић (2018): Николета Момчиловић, Немачки као gруіи стирани језик y Србији, докторска дисертација, Београд: Универзитет у Београду - Филолошки факултет.

Марфи (2003): S. Murphy, Second Language Transfer During Third Language Acquisition, преузето јануара 2017. ca: https://journals.cdrs.columbia.edu/wp-content/ uploads/sites/12/2015/05/3.-Murphy-2003.pdf.

Одлин (1989): Terence Odlin, Language transfer: Cross-linguistic influence in language learning, Cambridge: Cambridge University Press.

Радовић (2014): Danijela Radović, Međujezički uticaji u procesu usvajanja trećeg jezika, doktorska disertacija, Novi Sad: Univerzitet u Novom Sadu - Filozofski fakultet.

Рингбом (1986): Håkan Ringbom, Cross-linguistic influence and the foreign language learning process, In: M. Sharwood Smith, E. Kellerman (Eds.), Cross-linguistic influence in second language acquisition, Oxford, UK: Pergamon Press, 150-162.

Рингбом (1987): Håkan Ringbom, The role of first language in foreign language acquisition, Clevedon: Multilingual Matters.

Рингбом (2001): Håkan Ringbom, Lexical transfer in L3 production, In: J. Cenoz, B. Hufeisen, U. Jessner (Eds.), Cross-linguistic Influence in Third Language Acquisition: Psycholinguistic Perspectives, Clevedon: Multilingual Matters, 59-68.

Сенос (2000): Jasone Cenoz, Research on multilingual acquisition, In: J. Cenoz, U. Jessner (Eds.), English in Europe: The Acquisition of a Third Language, Clevedon: Multilingual Matters Ltd, 39-53.

Сенос (2001): Jasone Cenoz, The effect of linguistic distance, L2 status and age on crosslinguistic influence in third language acquisition, In: J. Cenoz, B. Hufaisen, U. Jessner (Eds.), Cross-linguistic influence in third language acquisition: Psycholinguistic perspectives, Clevedeon, UK: Multilingual Matters, 8-20.

Синглтон (1987): David Singleton, Mother and other tongue influence on learner French: A case study, Studies in Second Language Acquisition, 9, Cambridge: CUP, 327-345.

Трамбле (2006): Marie-Claude Tremblay, Cross-linguistic influence and third language exposure: the role of L2 proficiency and L2 exposure, Otawa Papers in Linguistics, 34, Ottawa: University of Ottawa, 109-119.

Филиатова (2010): Ksenya Filatova, Third Language Acquisition, Macrocategories and Synonymy, In: M. Pütz, L. Sicola (Eds.), Cognitive Processing in Second Language Acquisition: Inside the Learner's Mind, Philadelphia: John Benjamins, 86-96.

Фолк, Бардел (2010): Ylva Falk, Camilla Bardel, The study of the role of the background language in third langauge acquisition. The state of the art, International Review of Applied Linguistics in Language Teaching, 48, 2/3, London: De Gruyter, 185-219.

Хамаберг (2001): Björn Hammarberg, Roles of L1 and L2 in L3 production and acquisition, In: J. Cenoz, B. Hufeisen, U. Jessner (Eds.), Cross-linguistic influence in third language acquisition: Psycholinguistic perspectives, Clevedon: Multilingual Matters, 21-41.

Џарвис, Павленко (2008): Scott Jarvis, Aneta Pavlenko, Cross-linguistic influence in language and cognition, New York: Rutledge. 


\section{Marija N. Vujović}

Foreign languages school "Logos"

Belgrade

\section{LINGUISTIC FACTORS THAT INFLUENCE TRANSFER}

Summary: The role of transfer that occurs during second language acquisition has been the subject of research studies on cross-linguistic influence, that aimed to explain how the existing linguistic knowledge influences the process of learning the target language. The main focus of interest of researchers dealing with this topic are the factors that influence the transfer. These factors can be linguistic and non-linguistic. The aim of this paper is to summarise the knowledge on linguistic factors that influence the transfer from the perspective of psycholinguistics, and outline the most relevant empirical research studies conducted in this field.

Keywords: transfer, cross-linguistic influence, factors, language distance, psychotypology, foreign language effect. 